\title{
Student Empathy Attitude in Supporting Competence as a Prospective Counselor
}

\author{
Hasan Bastomi \\ Institut Agama Islam Negeri (IAIN) Kudus \\ hasan@iainkudus.ac.id
}

\begin{abstract}
This study aims to determine the quality of the empathy attitude of the Islamic Education Counseling Guidance students of IAIN Kudus in Supporting Competence as a Prospective Counselor. This research uses qualitative methods with the type of field research (field research), data mining using questionnaires, observation, interviews and documentation then analyzed using a percentage descriptive table. The results showed that the empathy attitude of the students of Islamic Education Counseling Guidance was in the good category, namely $58 \%$. Although it is still regarded as unsatisfactory, it is a fundamental skill of the counselor. However, it is said that counseling students can develop their empathy better than students in other fields, such as medicine, nursing, and students in the social work field. Suggestions as Guidance and Counseling students are necessary to develop an obedient attitude both through lecture learning and in other forms of activity.
\end{abstract}

Keywords: Student, Empathy Attitude, Prospective Counselor

\section{Introduction}

The problems experienced by individuals are very diverse and complex. Many factors can become the background for the various problems that occur. Problem solving is very crucial in forming a healthy personality for individuals. Individuals who are unable to solve the problems at hand will hinder their development. The problems and forms of solution are increasingly diverse, depending on how the individual's perspective is in dealing with the problems at hand. With course this raises a very big need. The awareness of the form of help from others which can be accounted for theoretically and practically is 
enormous. Education in the formal pathway is a logical place for developing individuals to get professional help aimed at facilitating various problems and individual development. This is due to problems that appear to be substantially experienced by every developing individual.

Counselors have a very important role in improving the quality of education. Among the important roles of the Counselor is that the BK teacher plays a role in helping students to develop all their potential so that they can develop optimally, helping to recognize student potential, planning for the future and helping students overcome various student problems. On the other hand, Counselors also play a role in improving students' learning skills and motivation, assisting students in choosing majors, assisting students in adjusting to school, developing students' interests and talents, and helping to solve problems faced by students. Given the importance of the role of counselors in schools, there is a need for coaching and development in order to improve the skills and professionalism of counselors to ensure the achievement of quality education, especially in the aspects of guidance and counseling. ${ }^{1}$ The role of the counselor is to provide counseling and guidance services in schools to help students solve the problems they face so that students become independent individuals. This role is very necessary in schools so that teaching and learning activities can take place well as expected. ${ }^{2}$

Counseling is an interaction between two individuals called the counselor and the counselee, which occurs in a personal (professional) situation, created and fostered as a way to facilitate changes in the counselee's behavior which leads to solving the problems faced by the counselee. Being professional means that the counselee presents the problem at hand and the counselor creates an atmosphere of close relationship by applying the principles and techniques of counseling in such a way that the counselee's problem is explored in all its aspects and the counselee's person is stimulated to overcome the problem at hand using his own strength. ${ }^{3}$ The implementation of professional guidance and counseling services is supported by the competence of guidance and counseling teachers as service providers. One of the basic competencies

\footnotetext{
${ }^{1}$ Desty Kurniati, Tina Musyofah, and Aji Prayetno Ojil, "Pelaksanaan Supervisi Bimbingan Konseling Dalam Meningkatkan Keterampilan Layanan Konseling Guru BK SMA Kabupaten Rejang Lebong," Islamic Counseling: Jurnal Bimbingan Dan Konseling Islam 5 (1) (2021): 133-48, https://doi.org/10.29240/jbk.v5i1.2736.

2 Naelul Muna, "Strategi Guru BK Dalam Mengatasi Burnout Study Siswa SMKN 1 Widasari," Islamic Counseling: Jurnal Bimbingan Dan Konseling Islam 4 (1) (2020): 81-92, https://doi.org/10.29240/jbk.v4i1.1444.

${ }_{3}$ Prayitno and Erman Amti, Dasar-Dasar Bimbingan Dan Konseling (Jakarta: Rineka Cipta, 2013), 105.
} 
that must be possessed by guidance and counseling teachers is professional competence. $^{4}$

The application of counseling itself requires a counselor who meets the qualifications. According to Gibson \& Mithcell in Ramadhan \& Bahiroh, at least counselors must be trained, committed, and ethical. ${ }^{5}$ McLeod mentions several processes to become a counselor, namely being trained, undergoing counseling, and getting supervision. ${ }^{6}$ Corey argues that the characteristics of counselors are trying to have a healthy personality, being committed, undergoing counseling, understanding and being open to other beliefs. ${ }^{7}$

The counselor is an expert guidance and counseling service provider. Guidance and Counseling as a profession is described by the appearance of a counselor who can provide peace, comfort and new hope for clients. To become a professional counselor, one must display a warm, empathetic, honest, respectful attitude, and most importantly can be trusted (maintain the confidentiality of the counselee) ${ }^{8}$. Rogers in Sofyan S. Willis states that there are several competencies of counselors that can provide direct changes to the counselee during the counseling process, including: 1) Sincerity, 2) Acceptance. respect the counselee as a valuable individual, 3) Empathy, which is the ability to place yourself, the soul, and feelings of the counselor into the soul and feelings of the counselee. Some of these changes include the counselee being: 1) more realistic in seeing himself, 2) more confident and having the ability to direct himself, (3) more positive in self-assessment, 4) more mature, 5) able to handle stress it faces, 6) has a more healthy personality structure. ${ }^{9}$

The performance expectations of the counselor in providing expert guidance and counseling services are always driven by altruistic motives, empathy, respect for diversity, and prioritizing the interests of the counselee, by always paying close attention to the long-term impact of the services provided. The full figure of the counselor's competence includes academic and professional competences as a whole. Academic competence is the scientific basis of the tips for implementing professional guidance and counseling

${ }^{4}$ Alfi Rahmi and Nurhasnah, "Pengembangan Modul Seni Kreatif Dalam Memberikan Layanan Bimbingan Konseling Inovatif," Islamic Counseling : Jurnal Bimbingan Dan Konseling Islam 4, No 2 (2020): 163-80, https://doi.org/http://dx.doi.org/10.29240/jbk.v4i2.1833.

${ }_{5}$ Cahyo Setiadi Ramadhan and Siti Bahiroh, "Pemahaman Guru Bimbingan Konseling Tentang Nilai-Nilai Religiusitas Islam Dan Implementasinya Dalam Bimbingan Dan Konseling Kelompok," Islamic Counseling: Jurnal Bimbingan Dan Konseling Islam 5 (1) (2021): 15-42, https://doi.org/http://dx.doi.org/10.29240/jbk.v5i1.2051. 588-612.

${ }^{6} \mathrm{~J}$ McLeod, Introduction to Counselling, Fifth Edit (New York: Open University Press, 2013),

${ }^{7}$ Gerald Corey, Teori Dan Praktek Konseling Dan Psikoterapi (Bandung: Eresco, 2010), 19-26.

${ }^{8}$ Sigit Sanyata, "Perspektif Nilai Dalam Konseling: Membangun Interaksi Efektif Antara Konselor-Klien,” Jurnal Paradigma 2 (1) (2006): 10-13.

${ }^{9}$ Sofyan S. Willis, Konseling Individual Teori Dan Praktek (Bandung: Alfabeta, 2007), 45. 
services. Academic competence is the foundation for the development of professional competence, which includes: (1) understanding deeply the counselee served, (2) mastering the theoretical foundations and framework of guidance and counseling, (3) providing independent guidance and counseling services, and (4) developing personal and professional counselor on an ongoing basis. The counselor's performance is strongly influenced by the quality of mastery of the four competencies which is based on supportive personal attitudes, values, and tendencies. The academic and professional competence of the counselor in an integrated manner builds the integrity of the pedagogical, personal, social and professional competences. ${ }^{10}$

Altruistic motives in guidance and counseling services that are independent are indicated by one of the attitudes, namely empathy. Empathy is very important to form communication in the beginning of the counseling process. The counselor with an empathetic attitude will create a comfortable, trustworthy and honest atmosphere in the counseling process for the counselee. The counselor's high empathy attitude will later affect the service process provided. Given the counseling process is a help through interaction. One of the problems that often arises is the lack of empathy in communicating which can lead to misunderstandings in communication interactions so that the counselee is frustrated and there is no benefit resulting from the counseling process ${ }^{11}$.

The substance of empathy skills is that with this attitude, the counselee will openly share the problems faced by the counselor. However, empathy is something that is often ignored in the counseling process. The counselor considers that listening carefully and then giving a response is very representative of the counseling process without trying to put himself deeper into the position faced by the counselee. Listening carefully is different from the empathy process, although empathy starts from listening carefully.

The goals to be achieved in the counseling process can be effective if the conditions or climate allow clients to develop and explore their potential. This condition inevitably has to be created by the counselor considering its role as a facilitator in the counseling process. Rogers calls this condition a condition of facilitative counseling. These conditions are congruence (congruence), positive respect without conditions (positive regard), and empathy understanding. Other experts add conditions such as respect, and cultural awareness. ${ }^{12}$ The following is a brief explanation of these facilitative conditions.

10 ABKIN, Penataan Pendidikan Profesional Konselor Dan Layanan Bimbingan Dan Konseling Dalam Jalur Pendidikan Formal (Jakarta: ABKIN dan Depdiknas, 2008), 142.

11 Rizki Amalia, "Empati Sebagai Dasar Kepribadian Konselor," JURNAL PENDIDIKAN Dan KONSELING 1 No. 1 (2019): 56-58.

12 David Capuzzi and Douglas R. Gross, Counseling \& Psychotherapy; Theories and Interventions (New Jersey: Merril Prentice Hall, 1999), 90. 


\section{Congruence}

Congruence in a counseling relationship can be interpreted as "showing oneself" as it is, being straightforward and more importantly, there is an agreement between what is communicated verbally and non-verbally. Congruence in several other references has the same term as authenticity, genuineness. If the client knows that the counselor is incongruent, it can result in reducing and even losing the client's trust in the counselor. The counselor in the counseling relationship is expected to cause congruence in the client, meaning that the client has an attitude as it is, frankly, is not defensive because if the client has these attitudes it will hinder the counseling relationship.

2. Unconditional positive appreciation.

Counseling will be more effective if these positive reward conditions are created by the counselor and carried out unconditionally. In other words, the counselor accepts each individual (client) without judging personal aspects that are "weak" or "strong". Unconditional positive appreciation has the same meaning with warmth, care (respect). Thus a harmonious condition can be created between the counselor and the client and in this case the client can learn that he can with the existing reality be accepted by others as well as the client himself can accept himself as he is, both his weaknesses and strengths.

3. Understanding by empathy

Understanding empathetically is an ability to understand other people's point of view (thoughts, ideas) and feelings. Understanding empathically means that the counselor understands the client's perspective and feelings based on the client's own internal frame of reference. The counselor should think (with) the client rather than think about or about the client. With this condition, an effective counselor must live up to the client's feelings as clients perceive their feelings and their perspective on something. With an understanding empathically, the client will feel that there are other people who are willing and willing to understand himself that he has not previously obtained.

\section{Cultural awareness}

Cultural awareness refers to the counselor's ability to be open and motivated to learn to accept and understand a culture that is different from the culture he has, especially the culture that the client has. By using the client's cultural awareness, he does not impose his will (values) and at the same time contains the culture that the counselor has, but the counselor encourages the client to change what he should want according to the cultural values he has. ${ }^{13}$

13 Mulawarman, Buku Ajar Keterampilan Dasar Konseling (Semarang: Fakultas Ilmu Pendidikan UNNES, 2017), 8-10. 
The concept of empathy is a general term that can be used for the encounter, influence and interaction between personalities. Empathy is the meaning of the word "einfulung" which is used by German psychologists. It literally means "to feel in". Empathy comes from the Greek word "pathos", which means a deep and strong feeling that approaches suffering, and is then given the prefix "in". This word is parallel to the word "sympathy". But between the two there are differences. If sympathy means "feeling together" and leads to a state of deeper personal identification to a person, such that someone who is empathetic for a moment forgets or loses his or her identity. This deep and mysterious process of empathy takes place in a process of understanding, influence and other important forms of interpersonal relationships. ${ }^{14}$

Carl Rogers and Kohut defines empathy as a way to be with others to aid healing in psychotherapy. This usage is based on word meanings that emphasize the capacity to understand the experiences, thoughts, and feelings of others. Many theorists have seen empathy as a basic relationship skill necessary for understanding other people even at the most basic level. Kohut sees empathy as a response where someone thinks about the condition of another as if he is in the other person's position. Furthermore, Kohut reinforces his definition by saying that empathy is the ability to think objectively about the innermost life of another person. ${ }^{15}$ Meanwhile, Carl Rogers who is very active in the world of therapy offers two conceptions. First, he wrote that empathy is an attempt to see someone else's internal frame of mind accurately. Second, in understanding other people, the individual seems to enter into another person so that he can feel and experience what other people feel and experience, but without losing his own identity. Rogers definition is very important especially in the sentence "without losing one's own identity". The sentence contains meaning even though the individual puts himself in the position of others, but he still exercises self-control over the existing situation, is not made up, and does not drift into other people's situations. ${ }^{16}$

Allport defines empathy as the change in one's imagination into the thoughts, feelings, and behavior of others. Empathy lies between inference on the one hand, and intuition on the other. Allport also emphasizes the role of imitation in empathy. Empathy is a set of constructs related to an individual's response to the experiences of another individual. ${ }^{17}$ This construct specifically includes the process that occurs in the observer and the affective and non-

${ }^{14}$ Rollo May, Seni Konseling (Yogyakarta: Pustaka Pelajar, 2010), 72.

${ }^{15} \mathrm{H}$. Kohut, The Analysis of the Self: A Systematic Approach to the Psychoanalytic Treatment of Narcissistic Personality Disorders (Chicago: University of Chicago Press, 1971), 76.

${ }^{16}$ Carl Rogers, A Theory of Therapy, Personality, and Interpersonal Relationships: As Developed in the Client-Centered Framework (New York: McGraw Hill, 1959), 55.

17 G.W. Allport, Pattern and Growth in Personality (New York: Holt, Rinehart \& Winston, 1965), 98. 
affective results / outputs that are the result of this process. ${ }^{18}$ Empathy is also called a fundamental approach ${ }^{19}$ to support social life. ${ }^{20}$ Other scientists define empathy as an affective character that influences the experiences of other people's emotions ${ }^{21}$, cognitive ability to understand the emotions of others ${ }^{22}$. As a cognitive concept, Hogan describes empathy in global terms as an intellectual or imaginative ability to state the thoughts and feelings of others. ${ }^{23}$

Empathy is different from sympathy. Feelings of sympathy are often found in everyday life that describe one's feelings for others. The difference between empathy and sympathy is that empathy focuses more on the condition of the other person or the interlocutor and that person has already acted on the other person. Meanwhile, sympathy focuses more on one's own feelings for others, meanwhile the feelings of other people or the interlocutor are paid less attention and no action is taken.

The concept of empathy not only addresses a key process leading to and in effective counseling, but also includes the work of teachers, religious leaders and other occupations where the entire content of the work depends on the process of influencing others. Empathic is the ability with a variety of different definitions covering a wide spectrum, revolving around other people who create a desire to help, experience emotions similar to the emotions of others, know what other people feel and think, blur the lines between self and others.

Empathy can be subjective, interpersonal, or objective. ${ }^{24}$ Often empathy is a combination of the three. In counseling situations, empathy is the counselor's ability to bond with the counselee and reflect this understanding on them. This is done in various ways but empathy is essentially an attempt to think with, rather than for or about, the counselee and to absorb the counselee's communication, intentions, and understanding. ${ }^{25}$

${ }_{18}$ M. H. Davis, Empathy: A Social Psychological Approach (Dubuque: Brown \& Benchmark, 1996), 126.

${ }^{19}$ Sybil B. G Eysenck and H. J. Eysenck, "Impulsiveness and Venturesomeness: Their Position in a Dimensional System of Personality Description First Published," Psychological Report, 1978.

${ }^{20}$ M. L. Hoffman, Empathy and Moral Development (Cambridge: Cambridge University Press, 2000), 93.

21 Albert Mehrabian and Norman Epstein, "A Measure of Emotional Empathy1," Journal of Personality 40, no. 4 (December 1972): 525-43, https://doi.org/10.1111/j.14676494.1972.tb00078.x.

22 Robert Hogan, "Development of an Empathy Scale.," Journal of Consulting and Clinical Psychology 33, no. 3 (1969): 307-16, https://doi.org/10.1037/h0027580.

${ }^{23}$ Hogan, Development of an Empathy Scale, 65.

${ }^{24}$ Samuel T. Gladding, Konseling Profesi Yang Menyelurub (Yogyakarta: Pustaka Pelajar, 2012), 246.

${ }^{25}$ Gladding, Konseling Profesi Yang Menyeluruh, 248. 
Empathy is present when counselors can accurately feel the feelings of their counselee and can communicate these perceptions, so that the counselee knows that other people have entered the world of feelings without prejudice, projection or evaluation. ${ }^{26}$ Empathy means "to temporarily live someone else's life, moving in it with care without judgment". ${ }^{27}$ This means that in empathy, the identification process has an impact on inter-human understanding that can actually occur.

As Adler points out, this identification with a person appears to some extent in every conversation. Empathy is a fundamental process in love. In counseling, effective counselors seek to see and understand the problems faced by the counselee from the counselee's perspective. Adler recognizes empathy as a creative function in personality, by stating that empathy occurs when humans talk (to each other). It is not possible to understand other individuals if it is not possible to identify with the other person. If we look for the origin of this ability to act and feel as if we are someone else, we can find it in the existence of innate social feelings. In fact, it is a cosmic feeling and a reflection of the entire cosmic interconnectedness that exists within us; an inevitable characteristic of being human. $^{28}$

Based on some of the opinions above, it can be concluded that the meaning of empathy in counseling is a process in which the counselor basically sees and understands the problems and positions faced by the counselee from the counselee's point of view starting with identifying the feelings of the counselee's position. Empathy in counseling makes the counselor position himself as experienced by the counselee, but cannot be separated from what he should do as a counselor.

Empathy is defined as a feeling of sympathy and concern for others, especially to share experiences or indirectly feel the suffering of others. Hurlock in Asih and Pratiwi states that empathy is the ability to put oneself in another person's position so that other people seem to be part of oneself. Baron and Byrne in Asih and Pratiwi, explain that empathy is the ability to feel the emotional state of others, feel sympathetic and try to solve problems, and take other people's perspectives. ${ }^{29}$ In the research, Rizki Amalia explained that Empathy is the basis of the counselor's personality. In fostering the personality of the counselor to be able to communicate with clients and be able to feel what the client feels. The counselor must be able to feel what the client is feeling, thinking, and experiencing so that the counselor can enter the client's world and

${ }^{26}$ Jess Feist, Gregory J. Feist, and Sjahputri, Teori Kepribadian (Jakarta: Salemba Humanika, 2010), 19.

${ }^{27}$ Feist, Feist, and Sjahputri, Teori Kepribadian, 20.

${ }^{28}$ May, Seni Konseling, 76.

${ }^{29}$ Gusti Yuli Asih and Margaretha Maria Shinta Pratiwi, "Prilaku Prososial Ditinjau Dari Empati Dan Kematangan Emosi," Jurnal Psikologi Universitas Muria Kudus 1 No. 1 (2010): 33-42. 
understand the client's problems. ${ }^{30}$ In Sai Handari's research, Rosidah, and Eva explained that showing empathy in the counseling process will result in one condition, namely that the counselee is more heard, appreciated and feels that there are other people who are able to feel what he is feeling at that time. Thus, counselors with empathy attitudes are counselors who are able to place themselves deeper into the position faced by the counselee. The counselor as a whole enters the counseling process, so that he does not only think of himself as a counselor but is able to position himself as a counselee and tries to provide more understanding to the counselee through various kinds of interventions carried out. Based on this, empathy is important to be developed by counselors who will help facilitate the counselee in solving the problems at hand, and training is needed to display empathy so that the counseling service is more effective. Accurate empathy will help the counselor to be able to completely place himself in the counseling process ${ }^{31}$. In the research, Hasan Bastomi explains this is a challenge for prospective counselors (guidance and counseling students) today, because the times tend to make the younger generation exposed to what is referred to as the 'narcissism epidemic', where more and more students show egocentric qualities that are more individualistic and busy with improving their self-image compared to others. trying to understand what is happening in society. ${ }^{32}$

For this reason, students of Islamic Education Counseling Guidance as prospective counselors (BK teachers) are always required to increase knowledge about human behavior, both in the form of understanding for themselves and others. Related to understanding other people's conditions, Titchener in Taufik argues that a person cannot understand other people as long as he is not aware of the mental processes in him that are directed at other people. This understanding of others is what Titchener calls empathy. ${ }^{33}$ Thus, this research was conducted as a preliminary study to determine the quality of student empathy as a basis for developing empathy as a basic competency of Islamic Education Counseling students.

This study used a qualitative method with the type of Field Research (field research) with a total sample of 120 Islamic Education Counseling students IAIN Kudus students, extracting data using questionnaires, observation, interviews and documentation then analyzed using a percentage descriptive table.

30 Amalia, "Empati Sebagai Dasar Kepribadian Konselor."

${ }^{31}$ Sai Handari, Rosidah, and Eva, "Empati Sebagai Pengembangan Seni Konseling Untuk Efektivitas Pelayanan Konseling,” Lentera 18 (1) (2016).

32 Hasan Bastomi, "PERBANDINGAN SIKAP EMPATI MAHASISWA SEBAGAI CALON KONSELOR BERDASARKAN ANALISIS GENDER,” Ghaidan: Jurnal Bimbingan Konseling Islam \& Kemasyarakatan 4 (2) (2020): 64-75.

33 Taufik, Empati: Pendekatan Psikologi Sosial (Jakarta: Raja Grafindo Persada, 2012), 48. 
Students' empathy attitudes are observed by providing an assessment on a value scale and rating categories as follows. Very less $=1$, less $=2$, good enough $=3$, good $=5$, and very good $=5$. Attitude data Students' empathy attitudes are analyzed by calculating the value obtained from observations and the percentage of each aspect being assessed, namely the total value of each. the aspect is divided by all possible aspects and multiplied by 100 . If converted into a percentage, the range is $25-100$. The criteria are as follows; 25 - 43 categories Very poor, 44 - 62 categories Poor, 63 - 81 categories Good and 82 - 100 categories Very good. ${ }^{34}$

\section{Results and Discussion}

Empathy is a person's ability to recognize, perceive, and feel other people's feelings or it can also be interpreted as understanding other people's feelings or emotions, and a willingness to share what others feel and put oneself in someone else's condition. Empathy here allows one to understand feelings of joy, sadness, suffering, and other people's emotions such as anger, fear or others. A person who is empathetic will be able to know the thoughts and moods of others. In the counseling process, the counselor can position himself and understand what the counselee feels and experiences, and does not provide an assessment of what the counselee believes, whether positive or negative.

The counselor's empathy is one of the key factors that help clients solve personal problems. When we empathize with others, we put ourselves down and see the world through their eyes, imagine what it would be like to be them, and try to feel how they feel. In the counseling process. If clients feel understood, they will more easily open up to share their experiences and share these experiences with others. Clients who share their experiences in depth make it possible to assess when and where they need support, and the difficulties that require planning for change. And when clients see empathy in a counselor, they will be more comfortable. Therefore, it is important that a BKPI student as a prospective counselor has this empathy attitude, because this really helps the effectiveness of the implementation of the counselor (Yasfin, 2019). Especially now that teenage empathy has begun to erode, as reported by a study conducted by the University of Michigan in 2015. In the study, the researchers said that current college students or students showed 40 percent less empathy than students and students in the 1980s and 1990s. Which, according to the Institute For Social Research, Sara Konrath, the lack of empathy came after Face-to-face interactions began to decrease and replaced with social media such as Facebook and Twitter (Rahmawati, 2019). As a prospective counselor, a study conducted on BKPI students, IAIN Kudus students, about the attitude of empathy found the following results;

\footnotetext{
${ }^{34}$ Riduwan, Skala Pengukuran Variabel-V ariabel Penelitian (Bandung: Alfabeta, 2002), 15.
} 
The Frequency Distribution Table of the Empathy Attitudes of the Islamic Education Counseling students IAIN Kudus

Descriptive Statistics

\begin{tabular}{|l|r|c|c|c|c|}
\hline & $\mathrm{N}$ & $\begin{array}{c}\text { Minimu } \\
\mathrm{m}\end{array}$ & $\begin{array}{c}\text { Maximu } \\
\mathrm{m}\end{array}$ & Mean & $\begin{array}{c}\text { Std. } \\
\text { Deviation }\end{array}$ \\
\hline $\begin{array}{l}\text { Empati_skill } \\
\text { IIAIN_Kudus }\end{array}$ & 120 & 38,00 & 73,00 & 62,0917 & 5,71008 \\
Valid N (listwise) & 120 & & & & \\
\hline
\end{tabular}

Table of Acquisition Criteria Categories of Islamic Education Counseling students IAIN Kudus Students' empathy

\begin{tabular}{|l|r|r|}
\hline \multicolumn{1}{|c|}{ Kriteria } & \multicolumn{1}{|c|}{ Percentage } & \multicolumn{1}{c|}{ Amount } \\
\hline Very Less & $1 \%$ & 1 \\
\hline Less & $41 \%$ & 49 \\
\hline Good & $58 \%$ & 70 \\
\hline Very Good & $0 \%$ & 0 \\
\hline Total & $100 \%$ & 120 \\
\hline
\end{tabular}

After the data is presented in the form of a frequency distribution table, the data is then visualized in the form of a percentage as follows:

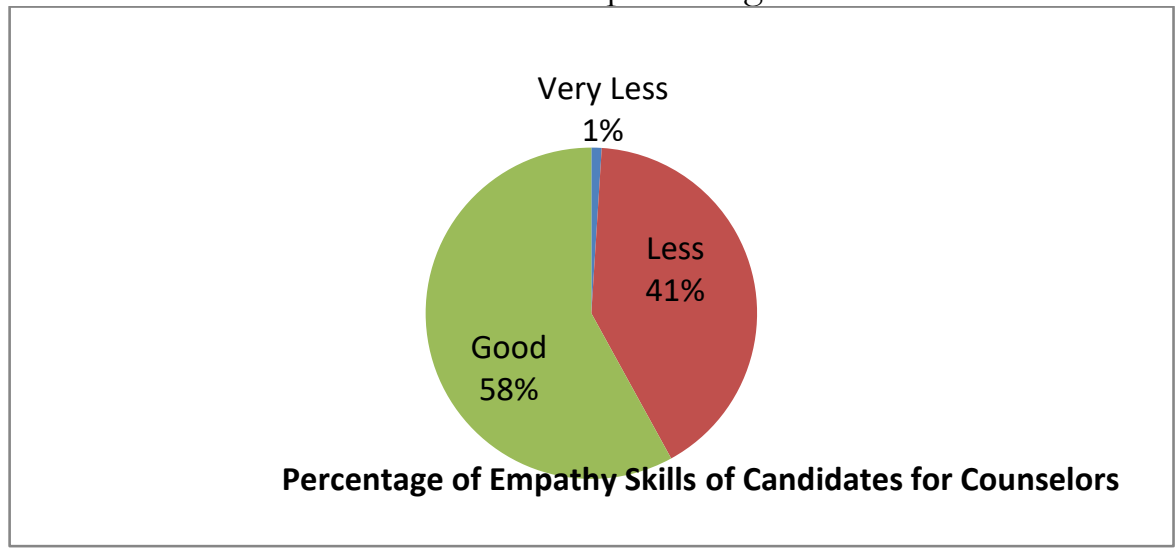

Figure The percentage of empathy of the Islamic Education Counseling students IAIN Kudus BKPI students

From the table above, it can be concluded that the score for the empathy process of the students of IAIN Kudus obtained for the very poor category is $1 \%, 41 \%$ less criteria and $58 \%$ good criteria. With the percentage of empathy as a potential counselor, it is felt that they are still lacking, so far some students have not fully shown empathy. So it is necessary to develop an attitude of empathy among students, by means of learning not only as a theory, but 
learning any subject must be directed about the importance of empathy as a basis for implementing counseling services. ${ }^{35}$

Such is the importance of empathy for a counselor in the implementation of counseling services, because empathy is able to comfort the counselee. With this percentage, according to Hasan Bastomi, as a teacher at the Islamic Education Counseling students study program, he feels very lacking. For example, this can be applied in the teaching and learning process, when there are still many students who chat alone with their friends so that they do not pay attention to what is conveyed by the lecturer, then it is a manifestation of students' inability to empathize with other people. Another form of neglect of empathy is when students do not do their assignments properly and arrive late, it is also a form of not empathy for the lecturer. Therefore there is a need for efforts to develop an empathetic attitude, both carried out by students independently and by lecturers and institutions in this case through study program activities. ${ }^{36}$

With a less than $41 \%$ percentage and a good half of it, $58 \%$, it is felt that it is still very minimal as a student counseling teacher candidate (counselor), this is because Islamic Education Counseling students socialization activities are still lacking, so it affects the lack of empathy that students have. ${ }^{37}$ Meanwhile, to respond to this, it is suggested the need to increase the attitude of empathy starting from oneself, because empathy is a basic attitude that a prospective counselor must have. As for the form of implementation in fostering empathy, for example by always participating in helping disaster victims by raising funds. If an attitude of empathy is embedded in us, social actions will emerge. ${ }^{38}$

In contrast to what was conveyed by Nailal Izaah, a third semester Islamic Education Counseling students student, with a high percentage of $41 \%$ empathy for the poor category and $58 \%$ for the good category. This is due to the fact that Islamic Education Counseling students have very low empathy towards their peers, especially towards the counselee (client). Islamic Education Counseling students are still carried away with the school atmosphere that is childish and with high egos so they don't care about their surroundings. Even though empathy is a fundamental mental attitude that a counselor must have, so it is not feasible to become a counselor now, it is necessary to develop an empathetic attitude that is personal or through the lecture process. ${ }^{39}$

35 Puspo Nugroho (Ketua Prodi BKPI), wawancara oleh penulis pada 2 September 2019

36 Anwar Yasfin (Dosen Prodi BKPI), wawancara oleh penulis pada 2 September 2019

${ }_{37}$ Muhammad Nor Zaki, (Mahasiswa BKPI semester 3), wawancara oleh penulis pada 3 September 2019 2019

${ }^{38}$ Sri Norhayati, (Mahasiswa BKPI semester 3), wawancara oleh penulis pada 3 September

${ }^{39}$ Nailal Izzah, (Mahasiswa BKPI semester 3), wawancara oleh penulis pada 3 September 2019 
The results in this study indicate that it turns out that the guidance and counseling learning received by students is beneficial in developing their empathy. This is based on the findings of Islamic Education Counseling students empathy attitudes in the good category, namely 58\%. Although as a prospective counselor, these findings are not considered encouraging, but in this regard, a previous study has examined the picture of empathy in students in the health-care field consisting of medical, nursing, social worker, and counseling students. The results show that students in the social work field have a higher level of empathy than medicine and nursing, and that counseling students have a higher level of empathy than the social worker field ${ }^{40}$. Thus, it can be said that counseling students can develop their empathy more than students in other fields, such as medicine, nursing, and students in the field of social work.

\section{Conclusion}

Guidance and counseling learning received by students is useful in developing their empathy. This is based on the findings of Islamic Education Counseling students empathy attitudes in the good category, namely 58\%. Although it is still considered unsatisfactory, it can be said that counseling students can develop their empathy more than students in other fields, such as medicine, nursing, and students in the social work field.

The empathy attitude found in the results of the study, namely $58 \%$, was felt to be still lacking as a potential counselor who made empathy a basic skill in counseling. So as a student of Guidance and Counseling, it is necessary to develop an obedient attitude both through lecture learning and in other forms of activity. This is because the Islamic Education Guidance and Counseling Study Program at IAIN Kudus is a new study program that was established in 2016, so it does not yet have many generations. This has an effect on the number of samples taken and affects the lack of variation in research results. So in the future, if you do research on empathy for prospective counselors, you can take more samples from the campus that has long been established in the guidance and counseling study program.

\section{References}

ABKIN. Penataan Pendidikan Profesional Konselor Dan Layanan Bimbingan Dan Konseling Dalam Jalur Pendidikan Formal. Jakarta: ABKIN dan Depdiknas, 2008.

Allport, G.W. Pattern and Growth in Personality. New York: Holt, Rinehart \&

40 Chato Rasoal et al., "Ethnocultural Empathy Among Students in Health Care Education," Evaluation \& the Health Professions 32, no. 3 (September 20, 2009): 300-313, https://doi.org/10.1177/0163278709338569. 
202 | Islamic Counseling: Jurnal Bimbingan dan Konseling Islam, Vol. 5, No. 2, 2021

Winston, 1965.

Amalia, Rizki. "Empati Sebagai Dasar Kepribadian Konselor." JURNAL PENDIDIKAN Dan KONSELING 1 No. 1 (2019): 56-58.

Asih, Gusti Yuli, and Margaretha Maria Shinta Pratiwi. "Prilaku Prososial Ditinjau Dari Empati Dan Kematangan Emosi." Jurnal Psikologi Universitas Muria Kudus 1 No. 1 (2010): 33-42.

Bastomi, Hasan. "Perbandingan Sikap Empati Mahasiswa Sebagai Calon Konselor Berdasarkan Analisis Gender." Ghaidan: Jurnal Bimbingan Konseling Islam \& Kemasyarakatan 4 (2) (2020): 64-75.

Capuzzi, David, and Douglas R. Gross. Counseling \& Psychotherapy; Theories and Interventions. New Jersey: Merril Prentice Hall, 1999.

Corey, Gerald. Teori Dan Praktek Konseling Dan Psikoterapi. Bandung: Eresco, 2010.

Davis, M. H. Empathy: A Social Psychological Approach. Dubuque: Brown \& Benchmark, 1996.

Eysenck, Sybil B. G, and H. J. Eysenck. "Impulsiveness and Venturesomeness: Their Position in a Dimensional System of Personality Description First Published." Psychological Report, 1978.

Feist, Jess, Gregory J. Feist, and Sjahputri. Teori Kepribadian. Jakarta: Salemba Humanika, 2010.

Gladding, Samuel T. Konseling Profesi Yang Menyeluruh. Yogyakarta: Pustaka Pelajar, 2012.

Handari, Sai, Rosidah, and Eva. "Empati Sebagai Pengembangan Seni Konseling Untuk Efektivitas Pelayanan Konseling.” Lentera 18 (1) (2016).

Hoffman, M. L. Empathy and Moral Development. Cambridge: Cambridge University Press, 2000.

Hogan, Robert. "Development of an Empathy Scale." Journal of Consulting and Clinical Psychology 33, no. 3 (1969): 307-16. https://doi.org/10.1037/h0027580.

Kohut, H. The Analysis of the Self: A Systematic Approach to the Psychoanalytic Treatment of Narcissistic Personality Disorders. Chicago: University of Chicago Press, 1971.

Kurniati, Desty, Tina Musyofah, and Aji Prayetno Ojil. "Pelaksanaan Supervisi Bimbingan Konseling Dalam Meningkatkan Keterampilan Layanan Konseling Guru BK SMA Kabupaten Rejang Lebong." Islamic Counseling : Jurnal Bimbingan Dan Konseling Islam 5 (1) (2021): 133-48. https://doi.org/10.29240/jbk.v5i1.2736. 
May, Rollo. Seni Konseling. Yogyakarta: Pustaka Pelajar, 2010.

McLeod, J. Introduction to Counselling. Fifth Edit. New York: Open University Press, 2013.

Mehrabian, Albert, and Norman Epstein. "A Measure of Emotional Empathy1." Journal of Personality 40, no. 4 (December 1972): 525-43. https://doi.org/10.1111/j.1467-6494.1972.tb00078.x.

Mulawarman. Buku Ajar Keterampilan Dasar Konseling. Semarang: Fakultas Ilmu Pendidikan UNNES, 2017.

Muna, Naelul. "Strategi Guru BK Dalam Mengatasi Burnout Study Siswa SMKN 1 Widasari." Islamic Counseling: Jurnal Bimbingan Dan Konseling Islam 4 (1) (2020): 81-92. https://doi.org/10.29240/jbk.v4i1.1444.

Prayitno, and Erman Amti. Dasar-Dasar Bimbingan Dan Konseling. Jakarta: Rineka Cipta, 2013.

Rahmi, Alfi, and Nurhasnah. "Pengembangan Modul Seni Kreatif Dalam Memberikan Layanan Bimbingan Konseling Inovatif." Islamic Counseling: Jurnal Bimbingan Dan Konseling Islam 4, No 2 (2020): 163-80. https://doi.org/http://dx.doi.org/10.29240/jbk.v4i2.1833.

Ramadhan, Cahyo Setiadi, and Siti Bahiroh. "Pemahaman Guru Bimbingan Konseling Tentang Nilai-Nilai Religiusitas Islam Dan Implementasinya Dalam Bimbingan Dan Konseling Kelompok." Islamic Counseling: Jurnal Bimbingan Dan Konseling Islam 5 (1) (2021): 15-42. https://doi.org/http://dx.doi.org/10.29240/jbk.v5i1.2051.

Rasoal, Chato, Tomas Jungert, Stephan Hau, Elinor Edvardsson Stiwne, and Gerhard Andersson. "Ethnocultural Empathy Among Students in Health Care Education." Evaluation \&o the Health Professions 32, no. 3 (September 20, 2009): 300-313. https://doi.org/10.1177/0163278709338569.

Riduwan. Skala Pengukuran Variabel-Variabel Penelitian. Bandung: Alfabeta, 2002.

Rogers, Carl. A Theory of Therapy, Personality, and Interpersonal Relationships: As Developed in the Client-Centered Framework. New York: McGraw Hill, 1959.

Sanyata, Sigit. "Perspektif Nilai Dalam Konseling: Membangun Interaksi Efektif Antara Konselor-Klien.” Jurnal Paradigma 2 (1) (2006): 10-13.

Taufik. Empati: Pendekatan Psikologi Sosial. Jakarta: Raja Grafindo Persada, 2012.

Willis, Sofyan S. Konseling Individual Teori Dan Praktek. Bandung: Alfabeta, 2007.

Nugroho, Puspo, (Ketua Prodi BKPI), wawancara oleh penulis pada 2 September 2019

Yasfin, Anwar, (Dosen Prodi BKPI), wawancara oleh penulis pada 2 September 
204 | Islamic Counseling: Jurnal Bimbingan dan Konseling Islam, Vol. 5, No. 2, 2021

2019

Zaki, Muhammad Nor, (Mahasiswa BKPI semester 3), wawancara oleh penulis pada 3 September 2019

Norhayati, Sri, (Mahasiswa BKPI semester 3), wawancara oleh penulis pada 3 September 2019

Izzah, Nailal, (Mahasiswa BKPI semester 3), wawancara oleh penulis pada 3 September 2019 